\title{
In Other Worlds: Imagining What Comes Next. Introduction
}

Christine Lorre-Johnston and Fiona McCann

\section{(2) OpenEdition}

1 Journals

Electronic version

URL: https://journals.openedition.org/ces/7779

DOI: $10.4000 /$ ces. 7779

ISSN: 2534-6695

Publisher

SEPC (Société d'études des pays du Commonwealth)

\section{Electronic reference}

Christine Lorre-Johnston and Fiona McCann, "In Other Worlds: Imagining What Comes Next. Introduction", Commonwealth Essays and Studies [Online], 43.2। 2021, Online since 23 July 2021 connection on 06 February 2022. URL: http://journals.openedition.org/ces/7779 ; DOI: https://doi.org/ $10.4000 /$ ces. 7779

This text was automatically generated on 6 February 2022.

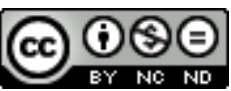

Commonwealth Essays and Studies is licensed under a Licence Creative Commons Attribution - Pas d'Utilisation Commerciale - Pas de Modification 4.0 International. 


\title{
In Other Worlds: Imagining What Comes Next. Introduction
}

\author{
Christine Lorre-Johnston and Fiona McCann
}

1 It is July 2021 and as we write this introduction, parts of Northern Europe have just experienced catastrophic flooding while Western parts of North America are facing yet another formidable and life-threatening heatwave. Earlier this year, southern parts of the USA experienced a polar vortex which translated into record-breaking low temperatures in Texas, Mozambique was devastated by the third cyclone to hit coasts there since 2019, flash floods occurred in Indonesia, displacing thousands, and after having experienced horrendous bushfires in 2020, this year Australia had to face strong flooding. And of course, there is the global pandemic which has exposed the vast inequalities in our world where the inhabitants of some nations (mostly in the Global North) have access to vaccines while others do not. The dystopian elements in the handling of COVID-19 will not have escaped anyone, and the subordination of collective well-being to profit-making through the refusal by pharmaceutical companies to unpatent their vaccines is already leading to the development of more and more dangerous mutations of the virus. These are but a few examples of the many natural disasters currently triggered by climate deregulation and an imminent catastrophe propelling us into if not another world, at least into a much less hospitable version of this one where our very survival as a species is threatened.

Writers of fiction have long experimented with ways to imagine our collective future, although their texts often say much about the present from which these futures are imagined, from H.G. Wells' and Ursula Le Guin's science fiction to Doris Lessing's Canopus and Argos series, and from Huxley's and Orwell's dystopian novels to Margaret Atwood's and Liz Jensen's more recent ones. In the past decade or so, the climate fiction genre, which is part of ecofiction but stresses the impact of climate change on the environment, has been developing ever more rapidly. Through necessary revisitings of the broad tradition of nature writing, "CliFi" has seen authors such as Kim Stanley Robinson, Barbara Kingsolver, E. Annie Proulx, and Richard Powers, among many 
others, publish best-selling novels all dealing with environmental collapse from different angles and generic approaches.

3 As Amitav Ghosh has pointed out, somewhat controversially, "the Anthropocene resists science fiction" because the world of the Anthropocene "is precisely not an imagined 'other' world apart from ours" $(2016,72)$. Here the distinction introduced by Margaret Atwood between science fiction and speculative fiction can shed light on what recent narratives of the Cli-Fi type do. For Atwood, science fiction deals with "things that could not possibly happen" - "an invasion by tentacled, blood-sucking Martians shot to Earth in metal canisters" - while speculative fiction is about "things that really could happen but just hadn't completely happened when the authors wrote the books" (2011, 6). In many of the contemporary works of ecofiction of the Cli-Fi category, it feels as if the degrees of separation between fiction and reality were tenuous; the things that happen, or another version of them, could very well happen in a not-so-distant future, or have already started to happen, in the here and now of our very own world.

4 Establishing an implicit connection between the ravages of capitalism and coloniality through a historically loaded lexical choice, Ghosh highlights "the literary mainstream's capitulation to the project of partitioning" of "literary fiction" and "science fiction" (2016, 72; our emphasis). Yet Ghosh's distinction here relies upon a fairly explicit hierarchy of literary value which perhaps runs counter to his call for humanity to "rediscover their kinship with other beings" so that a "vision, at once new and ancient, will find expression in a transformed and renewed art and literature" (162). For the challenge posed by the climate catastrophe has everything to do with our world view, and the evolution and outcome of the situation largely depend on it: "the climate crisis is also a crisis of culture, and thus of the imagination," Ghosh writes (9). Imagining other worlds - like imagining new literary forms and genres - is thus the key to re-imagining our own world, whichever degree of resemblance to it these other worlds bear.

Donna Haraway has cogently drawn attention to the fact that "[i]t matters what matters we use to think other matters with; it matters what stories we tell to tell other stories with; it matters what knots knot knots, what thoughts think thoughts, what descriptions describe descriptions, what ties tie ties. It matters what stories make worlds, what worlds make stories" $(2016,12)$. In this respect, it also matters what fiction is made visible and available for reading. All of the authors cited above are from the Anglo-American world, and although no one is disputing the importance of their voices, and the stories they tell so eloquently, the aim of this volume is to consider how a selection of postcolonial writers torque the genres of CliFi, Science Fiction, and Speculative Fiction in innovative and thought-provoking ways, in some cases incorporating ontologies and epistemologies which are far removed from Western empirical ways of knowing and much more connected to closely reading the land and sea.

6 It also matters what vocabulary we use, and as some thinkers have recently suggested, even the very term "Anthropocene" is potentially problematic in its implications that all humans are somehow equally responsible for the current situation and must equally share the burden. Other terms, such as Capitalocene (Moore 2016) or Plantationocene (Ferdinand 2019), displace the emphasis from humanity as a whole to systems of power and control and in so doing, call attention to the ways in which the toxic combination of capitalism and colonialism have pushed many species, including our own, to the 
brink of extinction. Postcolonial literatures have, of course, been interrogating and exposing the grim realities of the "colonial matrix of power" (Mignolo and Walsh 2018) for decades now, which is not to suggest that realism is the dominant mode. Yet what innovations, both aesthetic and political, can be observed in contemporary postcolonial speculative or science or climate fiction? This is precisely what this issue sets out to explore.

7 Kathie Birat's article on Mohale Mashigo's speculative short fiction takes us to South Africa and investigates the tension between a local and a global response to climate deregulation. The environment depicted by Mashigo is hostile and is shaped by the immediate threat of a major, yet undefined crisis irrevocably changing the world, a contributing factor in the difficulty of assigning an identity to the Intruders referred to in the title of the collection. Birat shows how Mashigo's short stories are simultaneously shaped by the post-transitional moment in South Africa and global capitalism, and she pinpoints the ways in which they borrow from various generic codes, including zombie fictions, in order to expose the ravages of drug addiction and poverty. Above all, far from reading Mashigo's stories as a series of personal epiphanies, often the dominant prism through which short stories are considered, Birat reveals the ways in which this South African author reassigns agency as a social force for change in her speculative fiction, in particular because that agency is not only reserved for the human species. This issue also contains a lengthy interview of Mohale Mashigo by Kathie Birat in which the author, prompted by Birat, reflects on the speculative fiction genre within a South African context, on gender questions, on the differences between writing short stories and writing a novel, and on specific aspects of the short story collection Intruders.

Two other South African authors, Frank Owen and Lauren Beukes, are discussed in the next article by Mélanie Joseph-Vilain who also interrogates the tension between the local and the global in these authors' dystopian fictions. Focusing on the apparent paradox of the "yet-to-come" of apocalyptic fiction (which implicitly announces an ending seemingly incompatible with any future), Joseph-Vilain analyses cross-Atlantic identities in novels by Owen and Beukes which are set in the United States and the social and political tensions represented in cross-temporalities. Disputing the claim made by critic Benjamin Kunckel that futuristic novels necessarily evade politics and ultimately constitute "literature' that isn't" (97), Joseph-Vilain argues that these novels are highly political in several ways: the connections between South Africa and the United States, or the reappraisal of these countries' histories, notably through the symbolic motif of the Wall which evokes the rigid racial boundaries which were rife in South Africa during Apartheid and in the United States at various times in history. The "yet-to-come" suggested at the end of Beukes' novel and Owen's diptych, Joseph-Vilain shows, is poised on the edge of the Atlantic Ocean where both the promise of a birth and a return to South Africa hint at an embracing of the hybridized racial, cultural, and historical identities which will constitute the future.

9 Claire Wrobel's article analyses recent speculative fiction by Margaret Atwood and in particular the ways in which the already existent potentialities of surveillance and intrusive digital technologies are explored. She suggests that ever since the publication of The Handmaid's Tale (1985) and with considerable frequency since the beginning of the $21^{\text {st }}$ century, Atwood has been anxious to tackle the question of surveillance in a series of dystopian novels. In these multiple other worlds which Atwood writes into 
being, mass surveillance is just one aspect of vaster projects of harvesting which go well beyond information to include body parts in worlds where, in ways which are strikingly similar to our own world, everything has become commodifiable. However, as Wrobel shows, what transpires in Atwood's speculative fiction is in fact her foregrounding of the consistent potential for resistance to and subversion of destructive forms of power. In Atwood's fiction, characters may be vulnerable, but so too are the systems of control used to coerce and contain individuals so that despite the violence often represented, hope springs eternal.

Many of the questions broached in the other articles are present in Laura Singeot's contribution on Aboriginal science fiction: cross-temporalities, transculturalism, and the tension between local and global in times of climate catastrophe. Writing against the grain of the colonial tropes of some science fiction, the two authors Singeot writes about, Alexis Wright and Claire Coleman, represent the desert as a heterotopia of immense temporal and spatial scales whose boundaries are unstable. Ultimately questioning the limits of humanity, notably in terms of our capacity for structural and physical violence, these novels, as shown by Singeot, also foreground uplifting potentialities for the development of new forms of community which are heavily influenced by Indigenous ontologies and epistemologies.

11 It is significant that several of the articles in this issue should focus on the African continent, especially since, as Cédric Courtois remarks in his article, young African climate activists are frequently airbrushed out of media representations which tend to favour the young white European activist Greta Thunberg. Courtois analyses a speculative short story by Osahon Ize-Iyamu and focuses in particular on the manner in which this young author foregrounds a specifically African, indeed Nigerian, Anthropocene where rising waters and chaotic waste management policies impact local inhabitants forced to develop new forms of resilience in order to survive. Courtois pinpoints the slippage Ize-Iyamu develops between humans and other animal species as a means of highlighting multiple vulnerabilities. Finally, Courtois argues that this short story, like much Cli-Fi, is didactic in its approach and aims to provoke readers to act, and react, before the hellish scenarios depicted become all too real.

This issue also contains a varia section, in which Jean-François Vernay, and Cielo G. Festino and Liliam Cristina Marins, discuss, respectively, sexual politics in 1970s (nonIndigenous) Australian literature, and the question of resistance and literature in translation. Vernay, taking Michael Wilding and Frank Moorhouse as examples, analyses the ways in which the subversive counter-culture of that time challenged mainstream heteronormativity, notably by highlighting a generation gap and by portraying more or less explicitly what Vernay calls "the joyous repertoire of sex" in relatively naturalistic fiction. Subversion and resistance are tackled from a very different angle in Festino and Marins' article which discusses the ways in which ideologies influence translations, with specific reference to the story "Draupadi" by Mahasweta Devi and its translation into English By Gayatri Spivak. They show how the several different discourses present in this story, and its translation by Spivak, frame readers' understanding of the many forms of resistance at play. Devi's story, in both its themes and aesthetics, is a political act, concerned with gender and anti-colonial struggles, and Spivak's translation adds yet another layer of political engagement and resistance. The final contribution in this varia section is an interview with the ArabAmerican author Laila Halaby by Ishak Berrebbah in which gender and family politics, 
diaspora, the question of different cultural traditions, and Orientalist stereotypes, especially in post-9/11 USA, are all discussed. Halaby also speaks of the ways in which Arabic storytelling and Western fairy tales are fruitfully deployed in her fiction as a means of giving depth to the often one-dimensional perceptions of Arab-American identity. These three pieces which are included in the varia section, while unrelated to speculative fiction or Cli-Fi, might perhaps nevertheless be seen to resonate with a more general understanding of "other worlds": how histories, stories and sexualities are mediated transculturally is central to all three pieces here, and how words and fiction imagine into being other worlds where political and stylistic forms of resistance (to patriarchy, heteronormativity, and cultural oppression) take centre stage.

\section{BIBLIOGRAPHY}

Atwood, Margaret. 2011. In Other Worlds: SF and the Human Imagination. London: Virago.

Ferdinand, Malcom. 2019. Une écologie décoloniale: Penser l'écologie depuis le monde caribéen. Paris: Seuil.

Ghosh, Amitav. 2016. The Great Derangement: Climate Change and the Unthinkable. Chicago: The University of Chicago Press.

Haraway, Donna. 2016. Staying with the Trouble: Making Kin in the Chthulucene. Durham, NC: Duke University Press.

Kunckel, Benjamin. 2008. "Dystopia and the End of Politics.” Dissent 55, no. 4 (Fall): 89-98.

Mignolo, Walter, and Catherine E. Walsh. 2018. On Decoloniality: Concepts, Analytics, Praxis. Durham: Duke University Press.

Moore, Jason W., ed. 2016. Anthropocene or Capitalocene? Nature, History, and the Crisis of Capitalism. Oakland, CA: PM Press.

\section{AUTHORS}

\section{CHRISTINE LORRE-JOHNSTON}

Université Sorbonne Nouvelle Christine Lorre-Johnston is Senior Lecturer in English at University Sorbonne Nouvelle in Paris. She has co-written, with Ailsa Cox, The Mind's Eye: Alice Munro's Dance of the Happy Shades (Fahrenheit, 2015) and co-edited Space and Place in Alice Munro's Short Stories: 'A Book with Maps in It' (Camden House, 2018), "Unsettling Oceania," a special issue of Commonwealth Essays and Studies $(41.1,2018)$, and "Afterlives of the Bible," a special issue of the Journal of New Zealand Literature $(36.2,2018)$. She is the current Editor of Commonwealth Essays and Studies and a CNRS Research Fellow in 2020-22. 


\section{FIONA MCCANN}

Université de Lille

Fiona McCann is a Professor of postcolonial literature in Lille University. She has published widely on contemporary Irish, South African and Zimbabwean literatures including a monograph entitled A Poetics of Dissensus: Confronting Violence in Contemporary Prose Writing from the North of Ireland (Peter Lang, 2014). More recent publications include an edited volume on The Carceral Network in Ireland History, Agency and Resistance (Peter Lang, 2020) and an article on "South African and Northern Irish Political Prison Writing: Reimagining/Reconfiguring the Prison Space" in Postcolonial Interventions, 2020. Her current research focuses on decolonial pedagogies and forms of care. 